\title{
Bosch 型エッチャーによるシリコン深掘り技術
}

\author{
野 沢 善 幸*1
}

\section{Advances in Deep Silicon Etch Processing Using Bosch Process}

\author{
Yoshiyuki NOZAWA*1
}

\begin{abstract}
${ }^{*}$ Process Department, Micro Technology Division Sumitomo Precision Products Co., Ltd.
\end{abstract} 1-10 Fuso-cho, Amagasaki, Hyogo 660-0891, Japan

(Received September 14, 2009, Accepted April 3, 2010)

\begin{abstract}
Deep Reactive Ion Etching ${ }^{1-3)}$ is well established as a commercial technique for forming Micro-Electro-Mechanical Systems (MEMS) devices. Over the last decade, development work has led to increases in silicon etch rate of an order of magnitude while requirements for etch depth uniformity and profile control have become more stringent as the wafer size has increased from 3 inch up to $200 \mathrm{~mm}$.

Many MEMS devices are still etched on $150 \mathrm{~mm}$ wafers, while most IC devices requiring Chip Scale Package (CSP) or other processing relating to Advanced Packaging will be manufactured on $200 \mathrm{~mm}$ wafers with planned moves to $300 \mathrm{~mm}$ wafers in progress or imminent.

This paper describes the leading edge technology of Deep Si RIE including high rate etching and Through Silicon Vias (TSVs) hole formation on wafers up to $300 \mathrm{~mm}$ in diameter.
\end{abstract}

\section{1.はじめに}

シリコン深掘り技術は, シリコン MEMS (Micro-ElectroMechanical Systems）デバイスの発展の駆動力となり，さ らに近年の MEMS デバイスの民生機器分野への普及に伴 い，その量産展開に必要な基本技術となっている.

MEMS デバイスの量産化のためには高精度, 高スループ ット, 高信頼性が必須であり, これらの要求が, シリコン深 掘り技術をさらに高度に洗練されたものに進化させてきた. 近年, 3 次元実装において, 配線長短縮の観点から導入が必 須と考えられているTSV (Through-Silicon-Via) エッチン グ技術にもシリコン深掘り技術の適用が検討されている.

本稿ではシリコン深掘り技術として, 既に MEMS では標 準となっているスイッチングプロセス（ボッシュプロセス） を取り上げ，種々の MEMSアプリケーション，TSVアプ リケーションへ展開する上で, 要求される性能とそれに対す る最適なソリューションについて,これまでの MEMS 量産 ラインで培われた実績を元に述べる.

\section{2. ボッシュプロセスと ASE プロセス}

\section{1 ボッシュプロセス ${ }^{1)}$}

シリコン MEMS 製造プロセスは，習熟された技術である 半導体製造プロセス（酸化・拡散，フォトリソ，エッチン グ，成膜等）の基本要素技術に, MEMS 特有の要素技術を 付加することにより，シリコン基板上にセンサーや機械的ス イッチ，駆動部などを作り込むものである. 機械的な動作を させるため, 厚い構造物が必要となる場合が多く, 速い加工 速度 (エッチング速度), 高いマスク選択比, 高精度な加工 が要求される.

$$
\text { シリコンプラズマエッチングにおいては，その取り扱いの }
$$

*1 住友精密工業株式会社 マイクロテクノロジー事業部 プロセ 又部（テ660-0891 兵庫県尼崎市扶桑町 1-10）
容易さ，エッチング速度の速さから，通常 $\mathrm{CF}_{4}$ や $\mathrm{SF}_{6}$ のよ うなフッ素を含むガスが用いられるが，プラズマ内で生成さ れたフッ素ラジカル（Fラジカル）とシリコンの反応は自発 的であるため等方的にエッチングが進み，そのままではマス ク通りの加工（異方性加工）が出来ない.

$-100^{\circ} \mathrm{C}$ 程度の低温でエッチングを行うと, 自発的反応を 抑え異方性が向上するが2), そのためには液体窒素による基 板冷却が必要で, 装置の複雑化, 維持管理費が増大する.よ り簡単に異方性加工を実施する方法として, 適当なガスを添 加してエッチング側面を耐エッチング性の高い材料で覆う方 法があるが3)，この方法では被エッチング面にもエッチング 阻止層が形成されるためエッチング速度が低下し, 深溝加工 には大きな問題となる.

この様な状況の下, 阻止層生成と, シリコンエッチングを 交互に繰り返すプロセスが独ロバート・ボッシュ社により開 発され深溝加工が容易になった.

ボッシュプロセスと呼ばれるこのプロセスは Laermer と Schilpにより発明された特許に基づいており，エッチング ステップ $\left(\mathrm{SF}_{6}\right.$ プラズマ) とパッシベーションステップ $\left(\mathrm{C}_{4}\right.$ $\mathrm{F}_{8}$ プラズマ) を交互に行ってシリコンをエッチングする. このプロセスの概略を Fig. 1 に示す.

まずパッシベーションステップでは CF 系重合膜がマスク を含めて全面に等方的に堆積される（Fig. 1(a)）.

次にエッチングステップでは基板にバイアスを印加してお くため, まず, エッチングされるパターンの底部の重合膜は イオンによるエッチングで除去されるが (Fig. 1(b))，イオ ンの方向性のため, 側壁の重合膜は除去されずに残る. その 後, エッチングパターン底部の露出したシリコンのみが F ラジカルによりエッチングされる，以上のシーケンスが繰り 返されてアンダーカットの無い異方性エッチングができる (Fig. 1(c)).

2.2 ASE (Advanced Silicon Etch) プロセス ${ }^{4-6)}$

当社子会社である SPTS (SPP Process Technology Sys- 


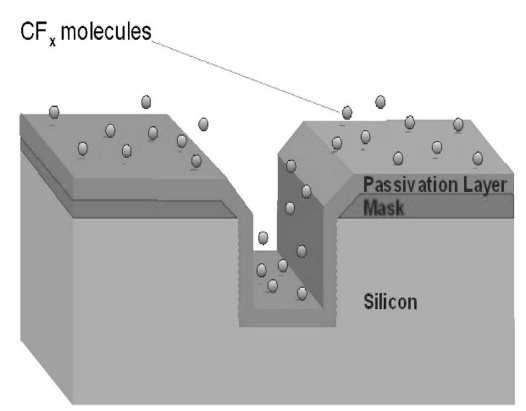

(a)

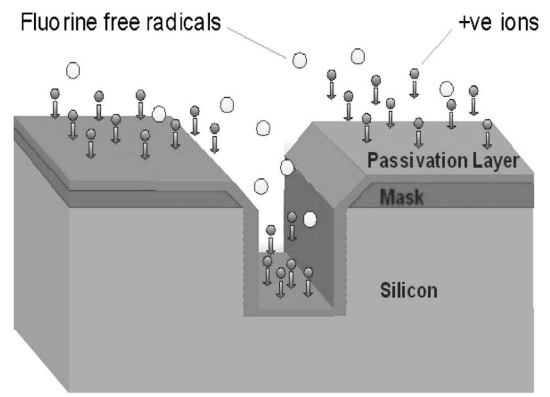

(b)

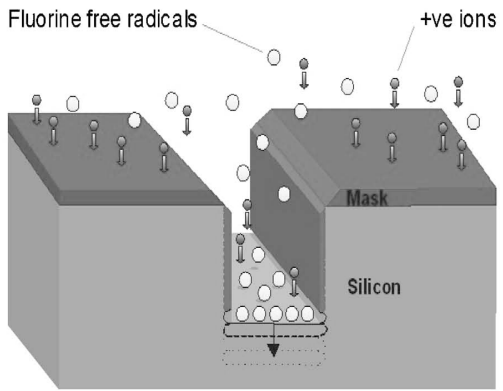

(c)

Fig. 1 Schematic view of Bosch Process.

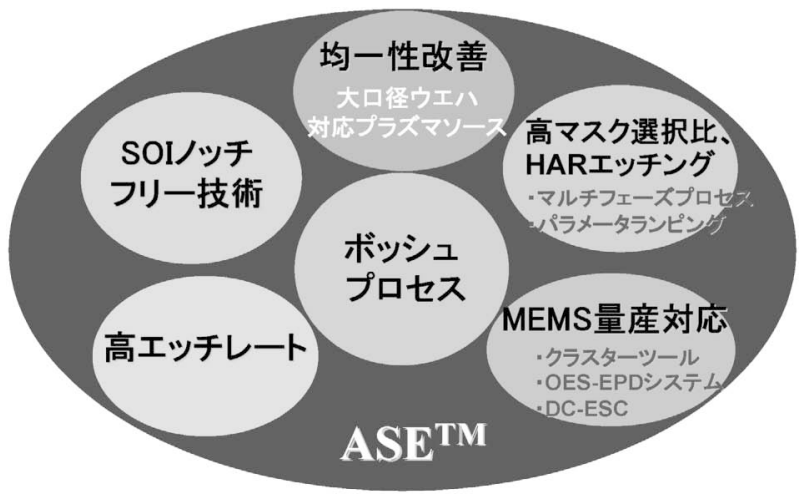

Fig. 2 Profile of ASETM (Advanced Silicon Etch).

tems）社は, ボッシュ社と共同開発したこのプロセスに, 独自の技術を付加し, 安定性, 応用性, 汎用性の高いプロセ スとして完成させ，ASE: Advanced Silicon Etch として商 標登録し，世界で初めてボッシュプロセス用の装置を提供し た。現在ではSPTS 社及び当社の 2 ヶ所で ASE 装置を製造 している。

Fig. 2 に ASE プロセスの構成を示す.

ASE プロセスは，特許技術である SOI (Silicon on insulator）ノッチコントロール技術7)や高アスペクト比エッチング プロセス技術（パラメータランピング8)，マルチフェーズプ ロセス）に加え, 高い冷却性能を持ち, ガラス張り合わせ基 板の吸着, 脱離も可能な静電チャック：DC-ESC (Direct cooling electro static chuck) や，高レートスイッチングプロ セス条件で, 数\%の開口率でも終点検知可能な発光分光式エ ッチング終点検知システムを搭載可能で，シリコン MEMS 製造技術のスタンダードとして広く全世界で採用されている.

\section{ASE プラズマエッチング装置}

\section{(ASE-HRMX, ASE-PEGASUS)}

ボッシュプロセスに適したプラズマソースとして，エッチ ング速度を確保するための高分解・高密度のプラズマが得ら れ，且つパッシベーションに拈いては低分解から高分解まで の制御性の良い条件設定ができる誘導結合型プラズマ (Inductively Coupled Plasma: ICP）を用いている（Fig. 3).

装置構成は，プラズマ発生室の外壁を誘電体で覆い，その 外周にアンテナコイルを配置する. アンテナコイルに高周波

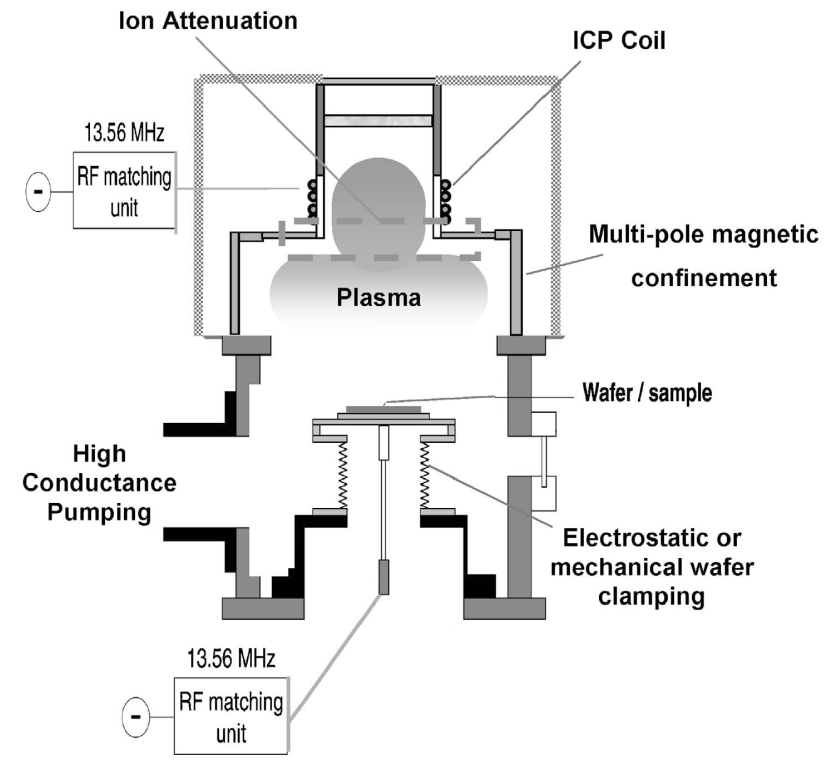

Fig. 3 Schematic of ASE-HRMX Process chamber.

電力を印加することにより，内部に発生する高周波磁界を利 用し，プラズマを発生させる. 比較的簡単な構造で高密度プ ラズマの生成が可能である，基板保持方式は静電チャックま たはメカニカルクランプによる方式があり, ウェーハにバイ アス電位を与えるために下部電極にも高周波電力を印加して いる.

ASE-HRMX 装置では反応室の上部に誘導結合型のプラ ズマ発生室を設け，効率的に高密度プラズマを作ってエッチ ングに必要な F ラジカルを生成し，ダウンストリームにあ るウエーハまで効率的にラジカルを輸送することにより高速 エッチングを実現している．同時に独自の機構によりイオン の入射エネルギーを減衰させ，側壁保護に有害な過度のイオ ン量を制御することにより，高いマスク選択比，高いエッチ ング速度で良好な形状のエッチングを達成した。 またチャン バ各部を効果的に温度制御し，量産時のエッチレートのドリ フトを最小限に抑えている.

ASE-PEGASUS 装置は，200 mm ウェーハでの量産に対 応したシリコン深掘り装置として開発されたものである。そ の特長は, エッチング形状の優れた面内均一性で, プラズマ 密度測定でもその均一性の良さを確認している。 また，エッ 
チング速度や選択比も ASE-HRMX 装置以上の性能を有し て抢り, 大口径ウェーハで且つエッチング形状の均一性が非 常に重要なアプリケーションにも対応している.

\section{4. 高アスペクト比ェッチングへのアプローチ}

近年の MEMS アプリケーションに㧍ける高精度加速度セ ンサ, アクチュエータ等の性能向上に対しては, より高アス ペクト比（エッチング深さ/エッチング寸法）の加工技術が 要求され, TSVアプリケーションに抢いてもアスペクト比 15以上を要求されることが多い. Fig. 4 に高アスペクト比 パターンのエッチングの例を示す．アスペクト比が高くなる につれ，トレンチ先端での先細りの形状になる場合が多い. この要因の一つとしては，エッチングパターンの高アスペク ト比化が進むと, トレンチが細孔と考えられ, そのコンダク タンスが低下し，トレンチ底面へのエッチング種の輸送や， 反応性生物の放出が悪くなるためと考えられる.

これを解消するには，一般的にプロセス圧力を低下させる ことやバイアス電力を上げることが考えられる．しかし，一 方で低圧力にするとラジカルの量が減少するためエッチング
速度が低下し, 高バイアス電力化により入射イオンのエネル ギーが増大するためマスク選択比の低下が起こる.

高アスペクト比エッチングにおいて，エッチング速度，マ スク選択比の低下を抑えて良好なエッチング形状を達成する

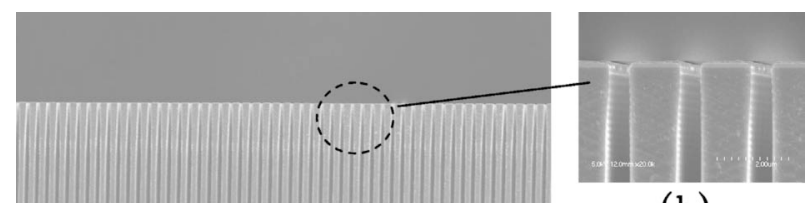

(b)

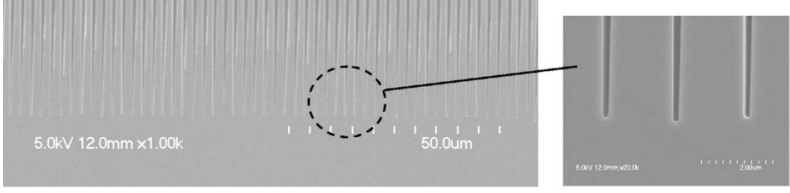

(a)

(c)

Fig. 4 Trench closes-up at high aspect ratio features, $0.8 \mu \mathrm{m}$ width and $58 \mu \mathrm{m}$ depth.

(a) Over view, (b) Magnified view around trench top,

(c) Magnified view around trench bottom.

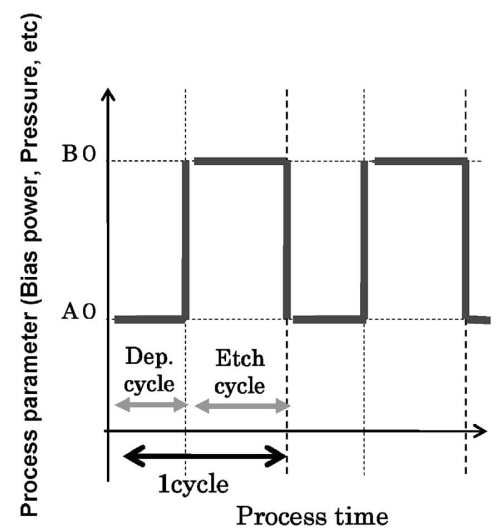

(a)

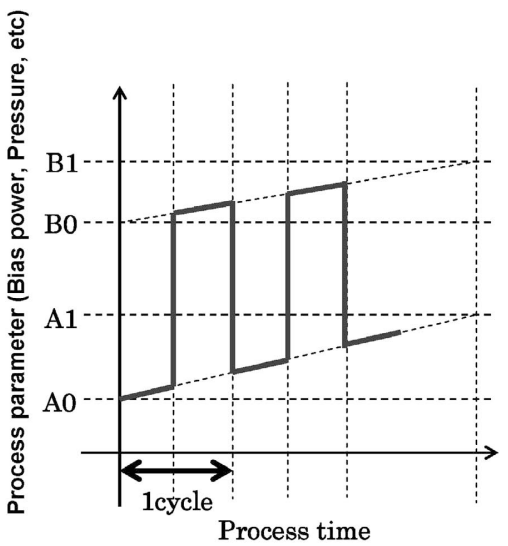

(b)

Fig. 5 Concept of parameter ramping.

(a) Normal process, (b) Parameter ramping.

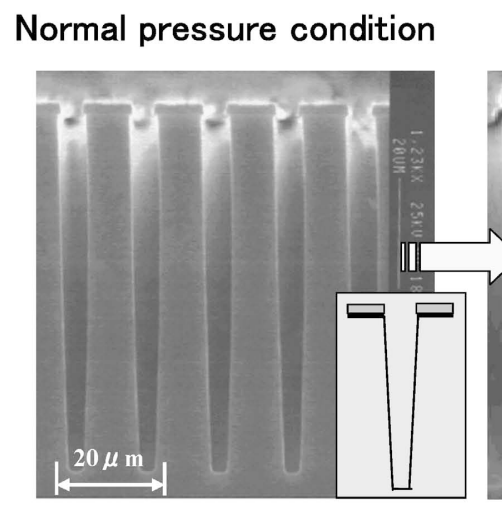

(a)

マスク(酸化膜)選択比 : 377 側壁角度: $88^{\circ}$

エッチレート: $2.1 \mu \mathrm{m} / \mathrm{min}$
Low pressure

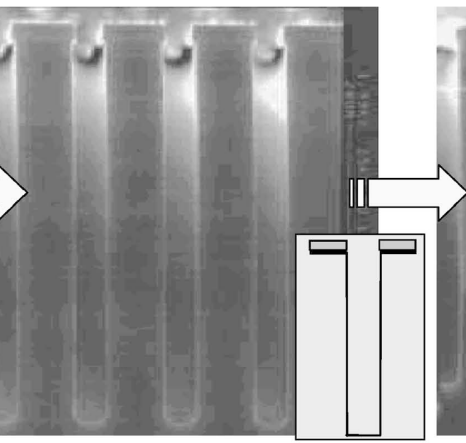

(b)

マスク(酸化膜)選択比：127 側壁角度: $90^{\circ}$

エッチレート: $1.4 \mu \mathrm{m} / \mathrm{min}$
Ramped high to low pressure

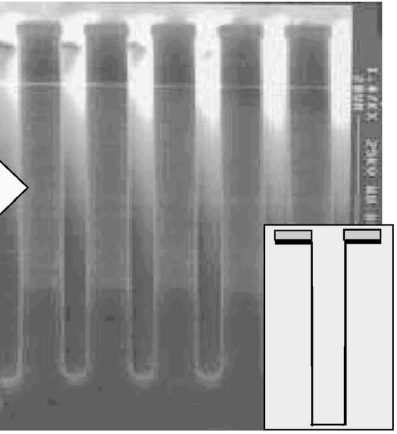

(c)

マスク(酸化膜)選択比：340 側壁角度: $90^{\circ}$

エッチレート: $1.8 \mu \mathrm{m} / \mathrm{min}$

Fig. 6 SEM Photographs of Silicon trench.

(a) Normal process, (b) Low pressure process, (c) Parameter ramping process. 


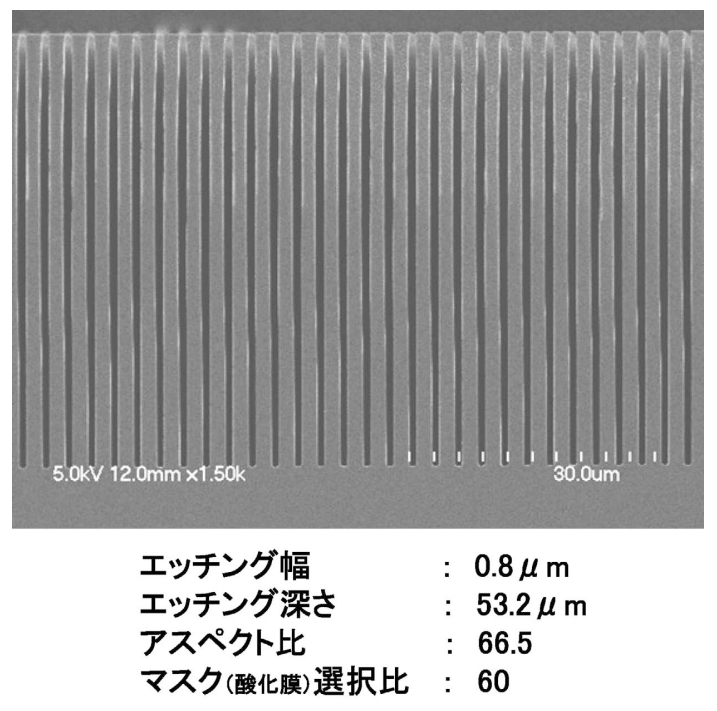

Fig. 7 High aspect ratio etching profile with features $0.8 \mu \mathrm{m}$ width and $53 \mu \mathrm{m}$ depth.

ためには，パラメータランピング8)が有効である．Fig. 5 に そのコンセプトを示す. 通常のプロセスでは, プロセス中に プロセスパラメータは一定である（Fig. 5(a))。パラメータ ランピングでは時間とともにプロセスパラメータを変化さ せ，常に最適な条件でエッチングを行う (Fig. 5(b)). Fig. 6 にパラメータランピングの適用例を示す。通常の圧力では トレンチの先端が細くなる (Fig. 6(a)). 先細り形状は圧力 の低圧力化で改善するが，マスク選択比，及びエッチング速 度は大きく低下する (Fig. 6(b)). 通常の圧力条件から低圧 力条件のランピングプロセスによりマスク選択比を維持し, エッチング速度を大きく低下させずに形状の改善を達成でき た (Fig. 6(c)). Fig. 7 にはパラメータランピング技術を適 用した高アスペクト比エッチングの結果を示す.アスペクト 比：66.5, マスク選択比：60 という非常に高い選択比で高ア スペクト比エッチングが達成できている.

\section{5. 側壁粗さ低減へのアプローチ}

\section{1 高速スイッチング対応システムの適用}

ボッシュプロセスでは Fラジカルによるシリコンの等方 的高速エッチングと CF 系ガスを用いたコンフォーマル CVD (Chemical vapor deposition) の繰り返しにより, シリ コンの高速深掘りエッチングを可能としている.しかし， 1 ステップの間は等方的にエッチングが進行するため, エッチ ング側壁にはスキャロップ (Scallops) と呼ばれる貝殼状の 形状が見られる (Fig. 8).

パワーデバイスや，シリコン貫通電極形成プロセス等のよ うに，後工程において埋め込反工程がある場合，もしくはミ ラーデバイス等のアプリケーションにおいては Scallops の 低減が重要である。この側壁形状の Scallops の大きさは, スイッチングの時間が短いほど低下するが，同時にシリコン のエッチング速度も低下する（Fig. 9)。我々は，スイッチ ング時間の短縮に伴うエッチングレートの低下は, エッチン グ|パッシベーション切り換え時のプロセスガス置換やプラ

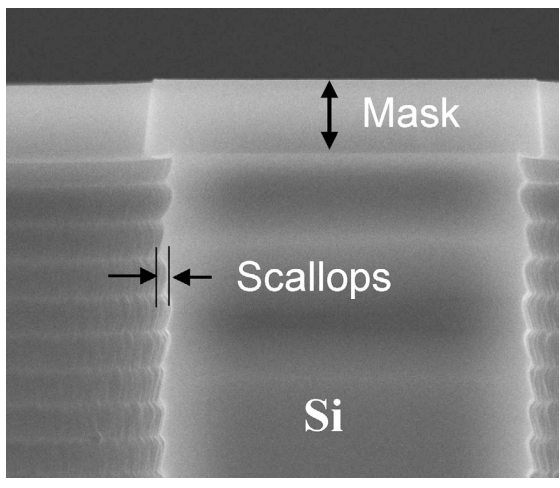

Fig. 8 Scallops.

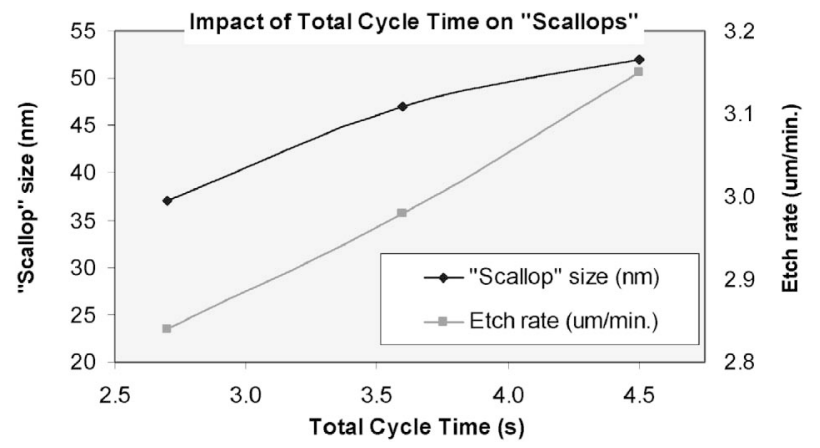

Fig. 9 Plot of scallop size and $\mathrm{Si}$ etch rate as a function of total cycle time.

ズマのマッチングが充分にできていないことが主な要因と考 え, 下記の改良を行った。

(1) 高速応答性 MFC (Mass flow controller) の採用

(2) プロセスガス供給システムの改良

(3) 高速応答性 APC (Adaptive pressure control) バルブ の採用

(4) 高速スイッチングに対応可能なマッチングシステム

Fig. 10に高速スイッチング対応ハードウエアでの低 Scallops プロセス性能を示す. Fig. 10(a) はエッチング断面形状 を, Fig. 10(b)はエッチング側壁面の粗さ（Scallops）を, AFMにより測定した結果を示す.

エッチング速度が $3.4 \mu \mathrm{m} / \mathrm{min}$ の条件でエッチング深さ $100 \mu \mathrm{m}$ の場合に抢いて, エッチング側壁面の側壁粗さ （Scallops）は8.9 nm（RMS）という低 Scallops の結果が得 られている.

5.2 パラメータランピング技術を用いたマスクアンダー カットの低減

トレンチパターンのエッチングに扔いて, マスクの初期幅 に対しエッチング後のトレンチ幅が広がる場合，この内側に 後退したエッチング幅をマスクアンダーカットと呼んでいる.

先に述べたようにボッシュプロセスは F ラジカルによる シリコンの等方的エッチングステップを含むので，このマス クアンダーカットが発生しやすい. Fig. 11にパラメータラ ンピング技術を用いたこのマスクアンダーカット，及び Scallops（側壁荒さ）の改善例を示す.

Fig. 11(a) は通常のスイッチング条件でエッチングした場 

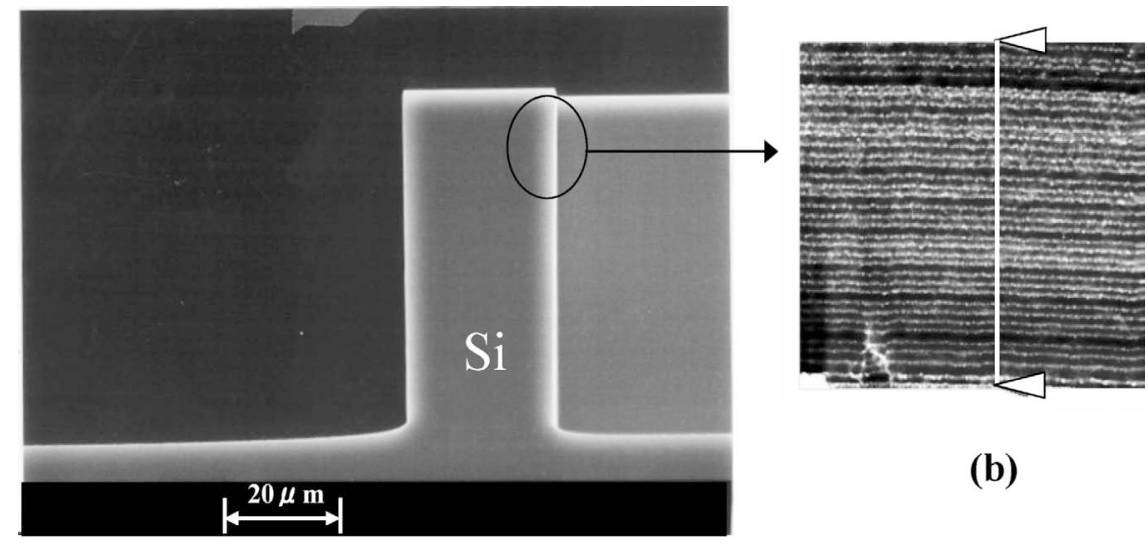

(b)

\section{(a)}

Fig. 10 Etching results with high speed switching.

(a) SEM Picture of etching pattern. (b) AFM profile along sidewall.

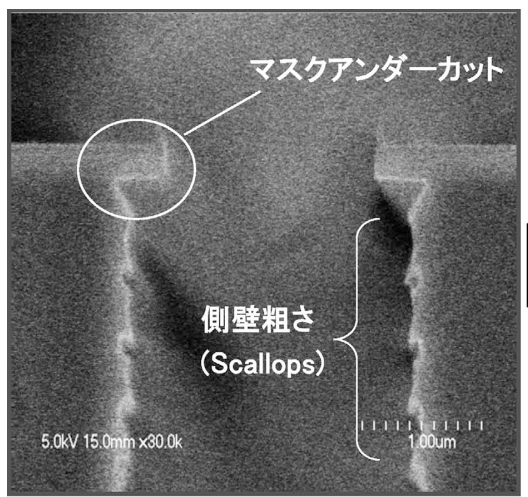

(a)

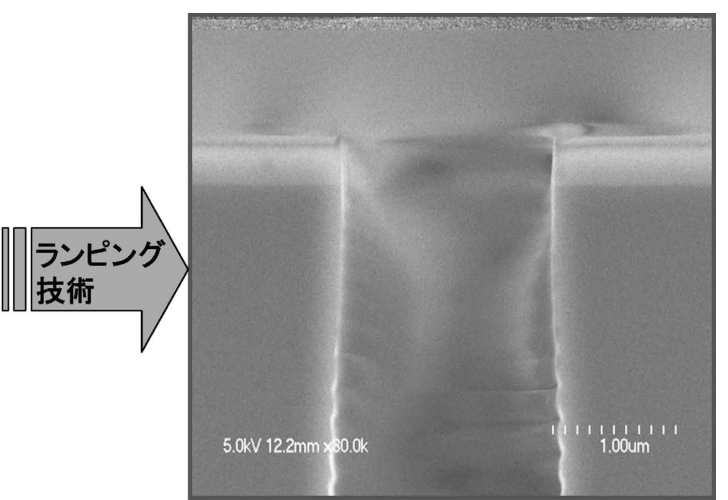

(b)

Fig. 11 Sidewall profile around trench top.

(a) Without parameter ramping. (Normal process), (b) With parameter ramping.

合のトレンチ上部の拡大 SEM 写真を示す。上述のマスクア ンダーカット，Scallops が見られる. Fig. 11(b)はエッチン グ開始時点では, Fig. 11(a)と比較して, 側壁保護を強化す る条件（例えば $\mathrm{C}_{4} \mathrm{~F}_{8}$ 流量を多く設定）を適用し，マスク直 下のサイドエッチングを防止させている．その後ランピング 技術を使って側壁保護の強さを少しずつ低減させ，エッチン グ速度の大きな低下を回避している。

\section{SOI ノッチレスプロセス}

シリコン深掘りエッチング後に酸化膜を犠牲層としてシリ コン構造体をリリースする様な MEMS アプリケーションに おいては, SOI 基板の酸化膜上にあるシリコンの貫通エッチ ングプロセスが必須となる.

この場合, デバイス特性に影響を及ぼすシリコン加工精度 の確保のため, 酸化膜界面に抢けるノッチング形状は避けな ければならない最重要項目である.

またシリコン貫通電極形成プロセスに扣いても, ウエハプ ロセス完了後, サポートウエハに貼り付けた研磨後のチップ を裏面からエッチングし, 絶縁層或いは $\mathrm{Al}$ のボンディング パッドまで貫通するプロセス（ビアラスト, 裏面ビアプロセ ス）があり, シリコンをオーバーエッチングしている際に発
生しやすいノッチング形状を防ぐ必要があるＦig. 12にノ ッチングの発生メカニズムと実例を示す.

ノッチングの発生は, エッチングがシリコン層からストッ パー層 (酸化膜層) に到達した時に, 酸化膜界面で正イオン が蓄積（チャージアップ）し, 次に入射してくる正イオンが 静電偏向によりトレンチ側壁をエッチングするために生じる と考えられている9-11).

SOI アップグレードシステムは, 酸化膜界面でのチャージ アップを抑えるハードウェアで, 試料台に印加するバイアス を工夫することでこのチャージアップ現象を緩和し，トレン チ側壁のノッチングを防いでいる12).

高アスペクト比パターンに拈いては，トレンチパターンで は底面の酸化膜界面のチャージは抜けにくいこともありノッ チングは発生しやすい. 一方, 残しパターンではノッチング はエッチング形状に大きな影響を及ぼす.

Fig. 13には高アスペクト比トレンチ構造のSOI エッチン グ結果を，Fig. 14には高アスペクト比柱状パターンの SOI エッチング結果を示す. SOIアップグレードシステムの適用 により, 双方の結果共ノッチの無い良好な結果が得られてい る. 


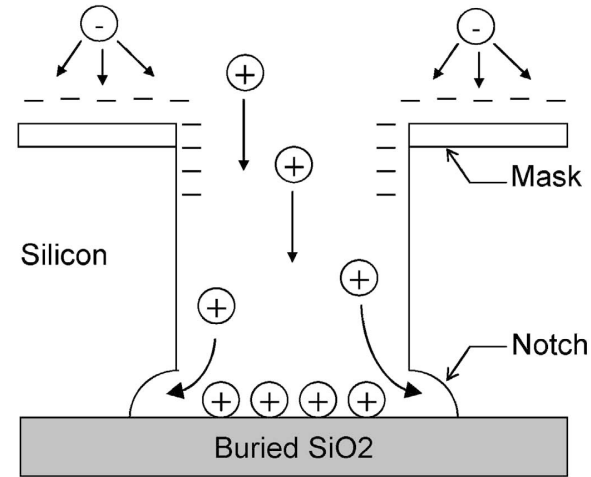

(a)

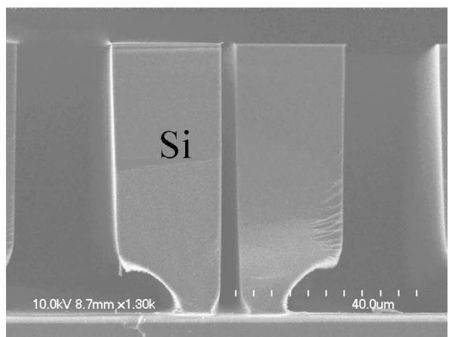

(b)

Fig. 12 (a) Formation mechanism of notch. (b) Typical example of notch.

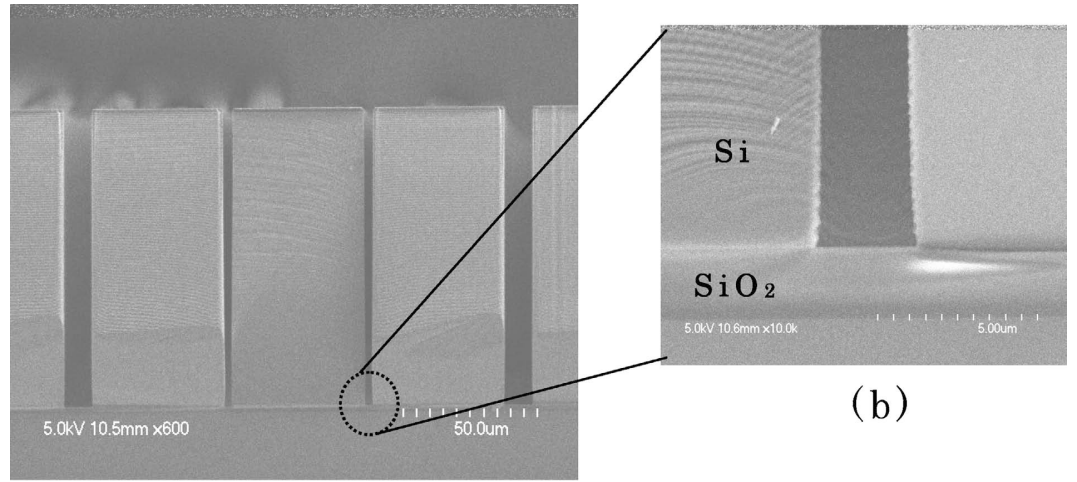

(a)

Fig. 13 High aspect ratio SOI etching profile for trenches. Minimum features sizes are $3 \mu \mathrm{m}$ width and $100 \mu \mathrm{m}$ depth. (a) Overview, (b) Magnified view around $\mathrm{Si}-\mathrm{SiO}_{2}$ interface.

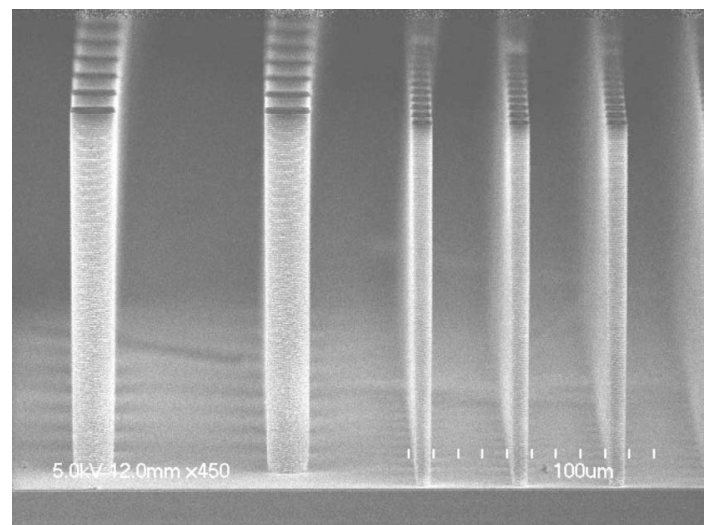

Fig. 14 High aspect ratio SOI etching profile for pillars. Minimum features sizes are $10 \mu \mathrm{m}$ diameter and $100 \mu \mathrm{m}$ depth.

\section{7. シリコン深掘り技術によるシリコン貫通ビア 形成}

次世代 LSI においては，さらなる高集積化に加え高性能 化, 高速化の要求に答えるべく, Fig. 15に示すように複数 のシリコンチップを積層させ，そのシリコンチップに直接貫 通孔を形成し, チップ間の接続を行う, シリコン貫通ビア (TSV) による配線形成技術が不可欠と言われている. 貫通
電極形成方法は, 各種シリコンデバイスチップに直接貫通孔 を垂直に開け, 絶縁層の埋め込久, バリア層, 電極埋め込久 用のシード層の形成, 配線材料の埋め込みの工程になる.

7.1 TSV 用ビアホール形成のためのシリコン深掘り技術 配線埋め込みのためのシリコン貫通ビア形成技術において は, 高速での加工を, 均一, 高精度に実施する技術が必要で ある. ボッシュプロセスを元に, シリコン MEMS 市場で長 年培われた技術を盛り込んだ ASE (Advanced Silicon Etch) は, TSVプロセスへ展開する上での各種要求について最適 なソリューションを具備している.

TSV工程には, トランジスタ形成工程の前に貫通ビア形 成を行うビアファースト，トランジスタ形成後に行うビアラ スト等があり, 種々の工程でビア径や深さは異なる. その上 でシリコン深掘り技術をTSVに適用する場合の一般的に要 求される項目をTable 1 にまとめる.

特に高エッチレートはスループットに直接影響し, ホール 側壁角度の制御, 及びスムーズな側壁形状は, 後工程での絶 縁膜埋め込久性能に影響するため, より高い性能が要求され る.

\subsection{TSV 埋め込み例}

Fig. 16に実際にビアのパターンを ASE プロセスでエッチ ングし, 絶縁層を埋め込み後, 下記手順で $\mathrm{Cu}$ を埋め込んだ 例を示す。 

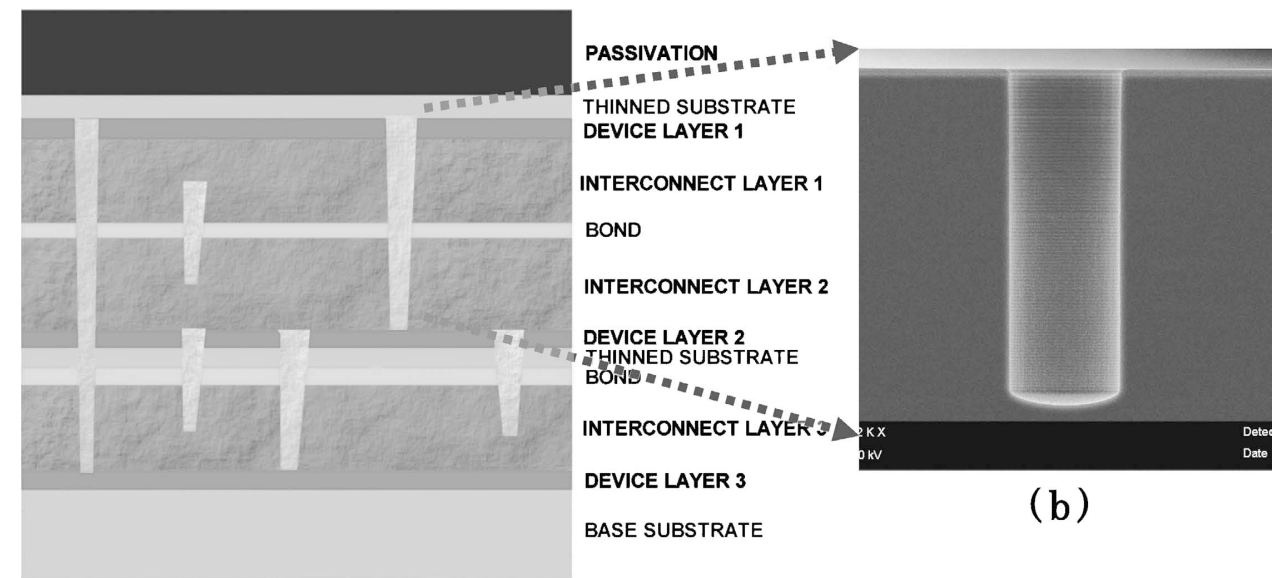

DEVICE LAYER 3

BASE SUBSTRATE

(b)

(a)

Fig. 15 (a) Schematic view of TSV Vias are etched Through substrates then metallized to form inter-layer. (b) Example of via etching profile with Features $60 \mu \mathrm{m}$ diameter etched to a depth of $200 \mu \mathrm{m}$.

Table 1 The process stages required to form a through wafer interconnect

・高エッチレート

・ホール側壁角度の制御

- Tilting 形状の改善

・高アスペクト比プロセス

・より滑らかな側壁形状

・マスクアンダーカットの抑制 (酸化膜までの Si 貫通プロセ ス)

- $300 \mathrm{~mm}$ 対応 DRIE

・薄いウエハの搬送

・貼り合わせウエハ（ガラス基
・酸化膜界面のノッチ量の制御 板), 裏面保護ウエハ (テー プ等) 対応.

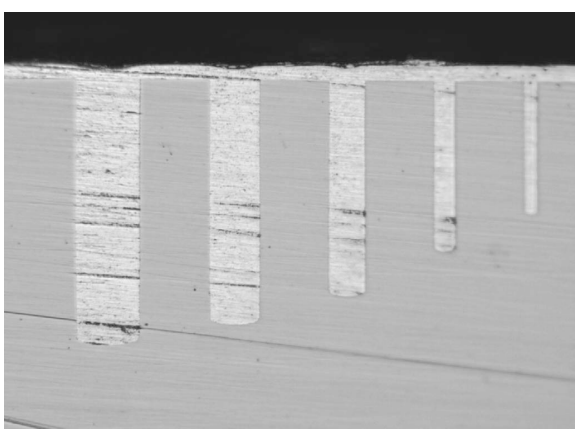

Fig. 16 A SEM showing $50 \mu \mathrm{m}, 40 \mu \mathrm{m}, 30 \mu \mathrm{m}, 20 \mu \mathrm{m}$ and 10 $\mu \mathrm{m}$ Vias etched using the ASETM process and filled with copper.

1) バリアメタルとして Ti $(50 \mathrm{~nm})$, シード層の $\mathrm{Cu} の$ 密着性あげるために $\mathrm{Cu}(100 \mathrm{~nm})$ を PVD で成膜

2) シード層 : $\mathrm{Cu}(300 \mathrm{~nm})$ を MOCVD で成膜

3） $\mathrm{Cu}$ を充填めっき

ボッシュプロセスで見られるエッチング側壁の Scallops があっても特に問題無く, 最小で $10 \mu \mathrm{m}$ 径のビアにも良好な 埋め込みができることを確認した。

\section{$7.3300 \mathrm{~mm}$ 対応プラズマソース}

シリコン深掘り技術をTSVに適用する上で，要求される 項目に300 mm ウエハ対応装置がある.

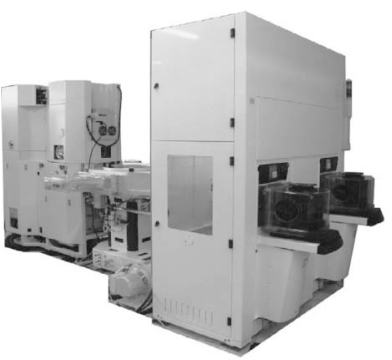

(a)

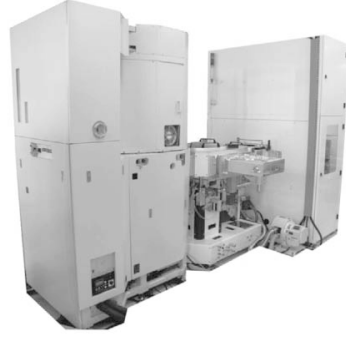

(b)
Fig. 17 ASE tool for $300 \mathrm{~mm}$ wafer. (a) Front view, (b) Back view.

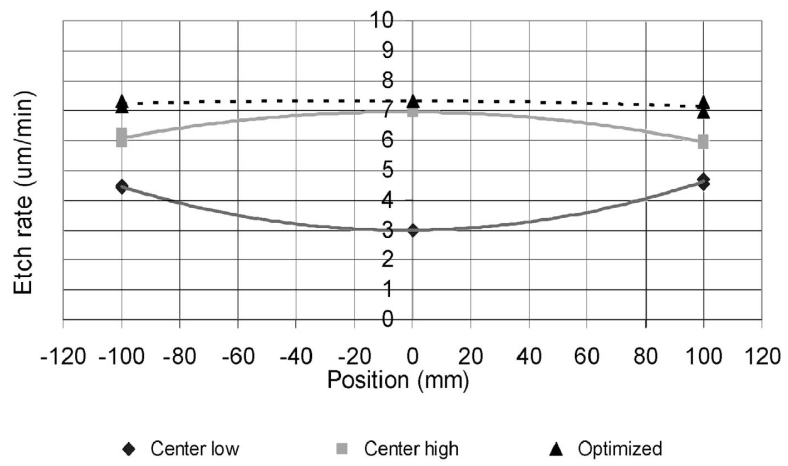

Fig. 18 Characterization : Etch Rate uniformity.

当社は MEMS 市場で実績のある $200 \mathrm{~mm}$ までのシリコン 深掘りエッチング用プラズマソースをもとに, $300 \mathrm{~mm}$ 対応 シリコン深掘りエッチング装置（PEGASUS-300）を開発， 2008年に発表した. Fig. 17に装置概観図を示す.

独自のプラズマソースコンセプトにより，300 mm ウエハ 全域に渡って均一なイオン密度分布を達成できるとともに, 中性ラジカル種の供給量もコントロールし, エッチング露出 面積に依存するローディング効果を抑制可能である.

Fig. 18は50 $\mu \mathrm{m}$ 径ビアのエッチング速度面内分布を, 各 種のプロセス条件での測定したものである. 


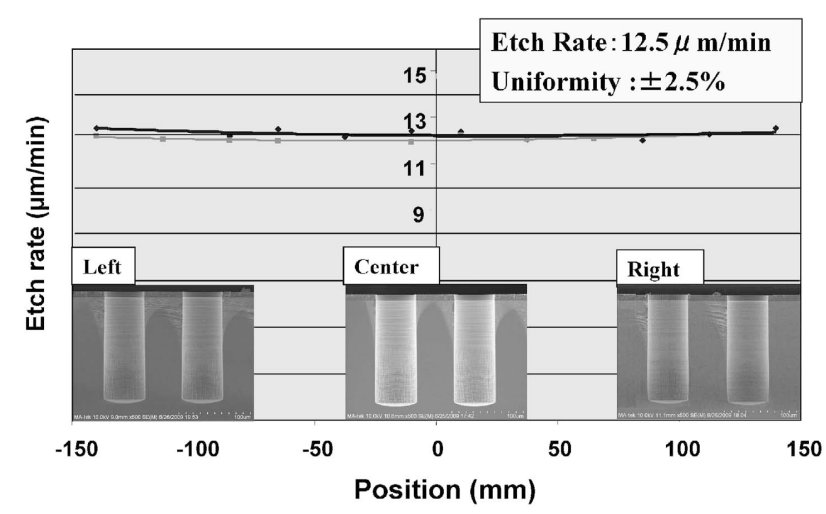

Fig. 19 Etch uniformity over a $300 \mathrm{~mm}$ wafer.

プロセス設定条件の適正化により, 面内均一なエッチング 速度分布から, ウエハ中央部のエッチング速度が早い分布, 遅い分布まで自在にコントロール可能である.

Fig. 19は300 mm ウエハに打る， $50 \mu \mathrm{m}$ 径ビアのエッ チング速度均一性である. プロセス条件を適正化した結果, エッチング速度は約 $12 \mu \mathrm{m} / \mathrm{min}$, 均一性は $\pm 2.5 \%$ と, 高い エッチング速度で良好な面内分布を達成している。

また, エッチング断面形状についても, ウエハ中央部から 外周部に渡り, 垂直形状が均一に再現できている.

\section{8. まと め}

ボッシュプロセスを用いたシリコン深掘り技術について, 当社の技術を中心に述べてきた.

MEMS デバイスやTSVアプリケーションの用途は大き く広がっているが, 技術トレンドの移り変わりは激しく, 新 規デバイスをいかにタイムリーに市場に提供するかが需要で あると考えられる。

従って，それらの要素開発について要する時間は最小にす ることが重要と思われる。
住友精密ではシリコン深掘り技術を中心に, 長年蓄積した 実績をもとに豊富なプロセスライブラリを持ち, 国内半導体 及び MEMS ユーザー各社の極めて多種多様なご要望に迅速 に対応するためのシステムを構築している.

今後も様々なアプリケーション開発・装置開発を通して益 々，多用途に拡がる MEMS デバイス開発やTSVアプリ ケーションに対し，早期に対応できる手段を提供できると考 えている.

\section{〔文献〕}

1) F. Laermer and A. Schilp: Method for anisotropically etching silicon, German patent DE4241045, 1992.

2) E. H. Klaassen, K. Petersen, J. M. Noworolski, J. Logan, N. I. Maluf, J. Brown, C. Storment, W. McCulley and G. T. A. Kovacs: Proc.Transducers'95, Stockholm, Sweden, 1995, pp. 556-559 “'Silicon fusion bonding and deep reactive ion etching; a new technology for microstructures",

3) J. K. Bhardwaj and H. Ashraf: Proc. SPIE, 1995, 2639, pp226227.

4) J. K. Bhardwaj and H. Ashraf: Proc. SPIE, 1995, 2639, pp224233.

5) J. K. Bhardwaj and H. Ashraf: Anisotropic dry silicon etching, Symp. Microstructures and Microfabricated Systems at the Annual Meeting of the Electrochemical Society (Montreal, Canada, 1997)

6) J. Hopkins, H. Ashraf, J. K. Bhardwaj, A. M. Hynes, I. Johnston and N. Shepherd: "Proceedings of the Materials Research Society Fall Meeting” Boston, MA, USA. December 1998.

7) J. K. Bhardwaj, J. Hopkins, H. Ashraf, A. M. Hynes, I. Johnston and L. Lea: US Patent, 6187685, Japan Patent 4163857.

8) J. K. Bhardwaj, J. Hopkins, H. Ashraf, A. M. Hynes, B. Khamsehpour, M. Ryan and D. Haynes: Patent 6051503, Japan Patent 3540129.

9) T. Nozawa, T. Kinoshita, T. Nishizuka, A. Narai, T. Inoue and A. Nakaue: JJAP, 34 (1995) 2107.

10) N. Fujiwara, T. maruyama and M. Yoneda: JJAP, 34 (1995) 2095.

11) A. A. Ayon, C. C. Lin, R. A. Braff and M. A. Schmidt: SolidState Sensor and Actuator Workshop, South Carolina, 41 (1998). 